\title{
HATOS GYULA KÖNYVE AZ ÉRTELMI AKADÁLYOZOTTSÁGGAL ÉLÖK ÉLETKILÁTÁSÁRÓL ÉS ÉLETKÍSÉRÉSÉRŐL (RECENZIÓ)
}

\section{A recenzió szerzője:}

Varga Imre

Szegedi Tudományegyetem

Szerző e-mail címe: varga.phdr@gmail.com

\section{Lektorok:}

Mezö Katalin

Debreceni Egyetem

Schéder Veronika

Debreceni Egyetem

Szilágyi Barnabás

Debrecni Egyetem

Koncz István

Professzorok az Európai Magyarországért

Egyesület

Varga Imre (2015): Hatos Gyula könyve az értelmi akadályozottsággal élők életkilátásairól és életkíséréséről (Recenzió). Különleges Bánásmód, I. évf. 2015/1. szám, 101-102. DOI 10.18458/KB.2015.1.101

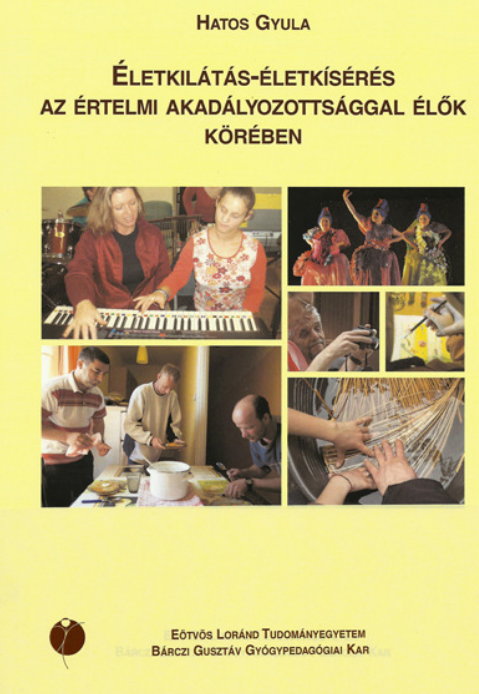

A recenzió alapjául szolgáló mü bibliográfiája:

Hatos Gyula (2012): Életkilátás-életkísérés értelmi akadályozottsággal élők körében. ELTE Bárczi Gusztáv Gyógypedagógiai Kar, Budapest. 325 oldal, ISBN: 978963-7155-56-7

Kulcsszavak: értelmi akadályozottság, életesélyek Diszciplina: gyógypedagógia, pedagógia

Bibliography of the subject of this recension: Hatos, Gyula (2012): Életkilátás-életkísérés értelmi akadályozottsággal élők körében. ELTE Bárczi Gusztáv Gyógypedagógiai Kar, Budapest. pp. 325, ISBN: 978963-7155-56-7

Keywords: intellectual disability, life chances Disciplines: special education, pedagogy

Hatos Gyula tanár úr tanítványaként, munkatársaként és barátjaként ajánlom gyógypedagógus hallgatóknak, gyógypedagógusoknak, pedagógusoknak és minden érdeklődő olvasónak, akik szeretnének minél többet tudni a támogatást igénylő társainkról a tanár úr által alkotott Életkilátás - életkísérés értelmi akadályozottsággal élők körében címü könyvet, ami 2012-ben az ELTE Bárczi Gusztáv Gyógypedagógiai Kar kiadásában jelent meg. 
Hatos Gyula $(\mathrm{PhD})$ gyógypedagógiai pályafutása során dolgozott mozgásterápiai intézetben, tanított gyógypedagógiai iskolában, internátusvezetőként működött gyógypedagógiai nevelőintézetben, a Bárczi Gusztáv Gyógypedagógiai Főiskola (mely jelenleg: az ELTE egyik karaként müködik) tanára, elnökségi tagja a Magyar Gyógypedagógusok Egyesületének. Röviden: a hazai gyógypedagógiai oktatás és kutatás legendás nagy alakja. Tanulmányain, jegyzetein és (idegen nyelven is megjelent) könyvein gyógypedagógus generációk „nőttek fel" az elmúlt évtizedek során.

Jelen írásban tárgyalt müve azért különösen figyelemre méltó, mert ez az első, felsőfokú oktataásban tankönyvként is használt munka hazánkban, amely az értelmi funkciók alacsony szintje, a kapcsolatteremtő képesség gyengesége következtében támogatást igénylö felnőtt emberek életét átfogóan mutatja be. Abból indul ki, hogy ezen emberek, embertársaink életét nem elsősorban a fejlődési sérülésből, „másságból” kiindulva, hanem emberi létük mindenkivel azonos értékü vonásaiból, erősségeik, jó tulajdonságaik és gyengeségeik egybevetéséből kell szemlélni, segíteni. Külön értelmezi náluk az értelmes, tartalmas élet megvalósításának lehetőségeit. Példamutató életutakat ír le.

A könyv első részében a felnőtté válással, a felnőtt korral foglalkozik. A serdülőkort, a családról leválást, a felnőtten betölthető szerepeket veszi sorra. Nagy teret ad a környezet hatásainak, a családban való életnek, és a társadalmi környezet, a médiák alakuló, sokszor még nehezítő oldalainak. Több helyütt kemény kritikával él. Külön szól az életet nehezítő jelenségekről: a nem nagyon ismert magányosságról, a viselkedés feltünőségeiről, amelyek sokféle gyökérből származhatnak, és ezek befolyásolásának módjairól. Izgalmas és új esetenként megdöbbentő - gondolatokat tartalmaz a veszélyekkel, bántalmazással, erőszakkal foglalkozó téma. Szól még az életminőség emelésének gondjáról, a támogatások - újabban bővülő rendszeréről.

A második részben az élet egyes területein jelentkező kérdéseket tekinti át. Indul a kapcsolatok, - barátságok, szerelem, párkapcsolat, szexualitás - bemutatásával, de a kényes kérdéseket, a szexuális visszaélést, a házasság lehetőségét, gyermekvállalást sem kerüli meg.

A különféle lakáslehetőségeket a jövő terveivel összefüggésben elemzi. Nagyon részletes a foglalkoztatás, munka és a szabadidő napjainkban egyre jobban előtérbe kerülö területének bemutatása. A széleskörü áttekintésből nem hagyja ki a falvakban élők helyzetét. Az idős emberek és támogatásuk gondolatkörével zárja mondanivalóját.

Minden fejezetben sok idézetet talál az olvasó, az érintettek, felnőttek, segítőik véleményét életükről: hogyan érzik magukat, hogyan fogadják az utat, - amely során gyakran kényszereket, csalódásokat is megélnek,- a támogatást, hogyan tudnak saját döntéseket hozni.

Több mint húszoldalnyi mellékletben felvonultatja a szerző a jelenkori szakirodalmat, bőséges külföldi kínálattal. Jogszabályokat, internetes honlapokat idéz. Részletes tárgy- és névmutatót ad, valamint idegen nyelvü összefoglalást. 